\title{
Why do Consumers Buy from Informal Sector Suppliers in East-Central Europe? A Case Study of Home Repair and Renovation Services
}

\section{Colin Williams", Brunilda Kosta*}

\begin{abstract}
This paper seeks to explain consumers' reasons for purchasing from informal sector suppliers so that policy initiatives can be developed to tackle the off-thebooks consumer culture. The conventional assumption is that those purchasing from the informal economy are marginalised populations seeking a lower price. Here, however this assumption is evaluated critically. Reporting data from a 2019 Eurobarometer survey involving 11,171 face-to-face interviews in 11 East-Central European countries on who purchases home repairs and renovations from informal sector suppliers and why, the finding is that it is not the poorest populations who purchase such services and a lower price is the sole motive in just $20 \%$ of cases. Besides being "pulled" into the informal economy by a lower price, consumers are also "pushed" into the informal economy by the failures of formal sector provision and in addition do so for social and redistributive rationales. The policy implication is that there is not only a
\end{abstract}

need to alter the cost-benefit ratio facing consumers so that they purchase formal services, but also initiatives are required to enhance the availability, speed, reliability and quality of formal sector provision and to address purchases made for social and redistributive reasons.

Keywords: informal sector; shadow economy; consumer behaviour; construction industry; East-Central Europe.

JEL: H26, J46, K42, O17, P37

\section{Introduction}

ver the past few decades, there have been major advances in explaining participation in the informal economy, or what is sometimes termed the "cash-inhand", "hidden", "undeclared" or "shadow" economy (Chen, 2012; Webb et al., 2009; Williams et al., 2013). However, these theorisations have focused upon explaining the supply-side, namely why employers and workers participate in the informal economy. Fewer attempts have been made to explain demand-side, namely consumers' reasons for purchasing goods and services from the informal economy. Nevertheless, to tackle the

\footnotetext{
* The University of Sheffield - Management, Management School

${ }^{\star *}$ University of Tirana Faculty of Economics - Management Department
} 


\section{Articles}

informal economy, understanding is needed not only of the reasons for its supply but also purchasers' rationales. In consequence, the aim of this paper is to advance understanding of consumers' reasons for acquiring goods and services from the informal economy. To achieve this, the focus of this paper will be upon why consumers purchase home repair and renovation services from informal sector suppliers in East-Central Europe.

This will advance understanding in three ways. Theoretically, it will not only call for the replacement of the marginalisation thesis, which asserts that groups marginalised from the formal market are more likely to purchase informal sector services, with a more nuanced understanding, but also show the need for a more variegated theorisation of consumers' rationales. Consumers acquiring services from the informal sector are not simply rational economic actors attracted by a lower price, but also pulled into the informal economy by the failures of formal sector provision and are in addition sometimes social actors doing so for social and redistributive rationales. Empirically, meanwhile, this paper reports for the first time up-to-date fresh empirical data from late 2019 on who purchases undeclared home repair and renovation services and why they do so based on a representative sample of 11,171 face-to-face interviews in 11 East-Central European countries, resolving the problem that the only previous study was conducted well over a decade ago. Finally, and in terms of policy implications, understanding is advanced by displaying the need for not only measures to change the cost-benefit ratio so that consumers purchase formal home repair and renovation services, but also policy initiatives to improve formal sector provision and to address informal sector purchases made for social reasons, along with an identification of the groups who need targeting by these different policy initiatives.

To commence, the first section provides a literature review on who purchases goods and services in the informal sector and their reasons for doing so. This will reveal that there has been only one study on purchasing home repair and renovation services in the informal economy reporting 2007 data. To evaluate who purchases informal home repair and renovation services and why in the present day, the second section then outlines the data and methods used, namely an analysis using logistic regression analysis of data collected in a late 2019 Eurobarometer survey in 11 EastCentral European countries (Bulgaria, Czech Republic, Estonia, Hungary, Latvia, Lithuania, Poland, Romania, Slovakia, Slovenia and Croatia). The third section reports the results, revealing the need for a more variegated and nuanced understanding of who purchases home repair and renovation services in the informal economy and their motives. The fourth and final section then discusses the theoretical advances in understanding the demand-side of the informal economy and the policy implications for tackling home repair and renovation services in the informal economy, along with the future research required and limitations of this study.

The consensus among both academics as well as policy-makers is that the informal economy refers to monetary transactions that are unregistered by and/or hidden from the state, for tax, social security and/or labour law purposes but that are legal in all other respects (European Commission, 1998, 2007, OECD, 2017; Williams, 2017; World Bank, 2019). It might be suggested that in practice, a consumer will not know if a supplier is declaring the income received from the purchaser for tax, social security and/or labour law purposes. Nevertheless, this is not a problem in this paper because the principal focus is 


\section{Articles}

consumers' rationales for intentionally and deliberately seeking to engage in transactions in the informal economy.

\section{Explaining the demand-side of the informal economy: a literature review}

Over the past decade or so, the informal economy has become a prominent issue on the agendas of supra-national agencies and national governments (European Commission, 2016; ILO, 2015; OECD, 2017; World Bank, 2019). This is because it has negative consequences for businesses, workers, consumers and governments. Formal enterprises suffer unfair competition from those operating in the informal economy (Andrews et al., 2011; OECD, 2017; World Bank, 2019). Meanwhile, businesses in the informal economy do not have legal protection, fear detection and are unable to access capital to expand (Loayza, 2018), and informal workers witness much poorer working conditions than formal workers (ILO, 2015; Williams and Horodnic, 2019). Importantly for this paper, purchasers of informal goods and services lack: insurance cover and legal recourse for poor quality work; guarantees about the quality of the work, and certitude that health and safety regulations have been applied (OECD, 2017). In addition, there are costs to governments, namely regulatory control over service provision and a loss of tax and social insurance revenue (ILO, 2018; World Bank, 2019). Consequently, tackling the informal economy is vital. However, unless the reasons for engaging in the informal economy are understood, policy solutions to address these reasons cannot be identified.

When explaining the informal economy and finding policy solutions, most scholarship has concentrated on the supply-side by seeking to explain and tackle employers and workers who engage in the informal economy. There have been studies of the different types of informal
Why do Consumers Buy from Informal Sector Suppliers in East-Central Europe?

work such as waged informal employment and informal self-employment (ILO, 2018; Williams, 2014; Williams and Yang, 2017), the characteristics of informal enterprises and workers (ILO, 2018; OECD, 2017; Williams and Bezeredi, 2019; Williams and Efendic, 2020; Williams and Yang, 2018; World Bank, 2019), and the reasons workers and businesses participate in the informal economy (Maloney, 2004; Shahid et al., 2019; Williams, 2019a; 2020a; 2020b; Williams et al., 2020; World Bank, 2019). There has been less scholarship on advancing understanding of the demandside. Here, in consequence, a comprehensive review is provided of the existing literature and theories on who purchases goods and services in the informal economy and their reasons for doing so.

\section{Who purchases informal goods and} services? The marginalisation thesis

Reviewing the literature, the dominant theory is that the informal economy is more prevalent in marginalised areas, such as poorer regions and rural localities (ILO, 2018), and in marginalised groups such as unemployed people, the less educated and those in financial difficulty (Slavnic, 2010; Taiwo, 2013). This marginalisation hypothesis derives from two dominant theories of the informal economy. In modernisation theory, which dominated in the twentieth century, the informal economy is conceptualised as a legacy of a previous mode of production and as persisting in peripheral populations that have not yet undergone economic development and modernisation (La Porta and Schleifer, 2008, 2014). In political economy theory, meanwhile, the informal economy directly results from the advent of a deregulated open world economy which has firstly, used sub-contracting to the informal economy as a means of reducing production costs and secondly, reduced social protection meaning that marginalised populations turn to the informal economy to 


\section{Articles}

secure their livelihoods in the absence of alternatives (Davis, 2006; Meagher, 2010; Slavnic, 2010; Taiwo, 2013). The informal economy is therefore conceptualised as "necessity-driven" activity undertaken by those excluded from the formal labour market welfare support mechanisms (Castells and Portes, 1989; Gallin, 2001).

Most of the evaluations of the marginalisation thesis have only considered the supply-side of the informal economy. Here, cross-country surveys have shown that the marginalisation thesis is valid but that a nuanced understanding is required when considering which marginalised groups are more likely to participate in the informal economy. Across Europe, some marginalised groups, such as the unemployed, those with difficulty paying household bills, and younger people, are shown to be more likely to work in the informal economy. However, other marginalised groups are shown not to be more likely to do so, such as those living in rural localities and those with less years in fulltime formal education. Yet other marginalised groups are shown to be significantly less likely to participate in the informal economy, such as people in deprived European regions and women (Williams and Horodnic, 2017).

When evaluating the demand-side of the informal economy and who is more likely to acquire goods and services from the informal economy, a much less nuanced understanding prevails. It is often simply assumed that those needing to pay a lower price (i.e., marginalised groups) are more likely to purchase from the informal economy. Take, for example, emerging economies. The informal economy is perceived as servicing "bottom of the pyramid" (BOP) markets, namely lower-income consumers who acquire cheaper goods and services from this realm (e.g., La Porta and Schleifer, 2008, 2014; World Bank, 2019). In transition and advanced economies, similar arguments prevail. The purchasers of goods and services from the informal economy are perceived to be mainly marginalised populations, including lowerincome populations, the unemployed and those who have financial difficulties in paying the household bills (Davis, 2006; Venkatesh, 2008).

The evidence of whether this is the case in East-Central Europe is thin. The only known study of who acquires goods and services from the informal economy reports data from 2013. The finding is that those significantly more likely to purchase goods and services from the informal economy are men, younger age groups, those with a lower tax morale, and those in employment. However, those with difficulties in paying the household bills are not significantly more likely to do so (Williams and Horodnic, 2016). It is therefore, not clearcut that it is only marginalised populations who are more likely to purchase informal goods and services.

Meanwhile, and turning to home repair and renovation services, no studies have been undertaken. Therefore, it is important to understand who purchases home repair and renovation services in the informal economy. If this sphere is to be tackled, it is also essential to understand the reasons for acquiring home repair and renovation services from the informal economy as well as who acquires them for each reason.

\section{The rationale of a lower price: rational economic actor theory}

Similar to the supply-side scholarship that views enterprises as operating in the informal economy to lower costs and gain financially, the demand-side literature depicts consumers as deliberately asking "how much for cash?" so that they can receive a lower price and gain financially (Bajada, 2002; Fortin et al., 1996; Gallin, 2001; Sassen, 1997). Consumers acquiring products and services from the 


\section{Articles}

informal economy are portrayed as rational economic actors who weigh up the benefits and costs of purchasing from the informal economy, and when the benefits outweigh the costs, they purchase informally. On the supply side, this rational economic actor perspective emerged in the early 1970s in the seminal work of Allingham and Sandmo (1972) who applied it to tax non-compliance. Since then, this perspective of workers and businesses engaging in the informal economy for the purpose of financial gain has become dominant.

From this rational economic actor perspective, the informal economy is tackled (both on the supply- and demandside) by altering the cost-benefit ratio facing suppliers and purchasers (Hasseldine and Li, 1999; Richardson and Sawyer, 2001). The resultant policy initiatives have mainly sought to increase the costs of engaging in the informal economy rather than the benefits of participating in the formal economy (Williams, 2019b; Williams and Puts, 2018). State authorities have increased the costs of engaging in the informal economy by increasing the perceived or actual probability of detection and penalties (Grabiner, 2000; Hasseldine and Li, 1999; Richardson and Sawyer, 2001). Recently, however, it has begun to be questioned if those participating in the informal economy are always purely rational economic actors wanting to obtain a lower price. The result has been alternative theorisations of participation in the informal economy.

\section{Social and redistributive rationales: social actor theory}

Rather than portray participants in the informal economy work as rational economic actors driven by cost/benefit calculations, an alternative theoretical perspective drives from broader critical, post-development, postcolonial, post-structuralist and post-capitalist
Why do Consumers Buy from Informal Sector Suppliers in East-Central Europe?

scholarship that questions the portrayal of monetary transactions as universally profitdriven market-like exchanges. Rather, a "thicker" depiction of monetary transactions is adopted which recognises the presence of multiple logics, including social logics (Bourdieu, 2001; Escobar, 1995; GibsonGraham, 2006; Leyshon et al., 2003; Zelizer, 2005).

This perspective has been recently applied to the informal economy. This has shown that informal work is frequently undertaken by and for closer social relations (e.g., kin, friends, neighbours and acquaintances) for social and redistributive rationales rather than purely for the purpose of financial gain (Cornuel and Duriez, 1985; Nelson and Smith, 1999; Persson and Malmer, 2006; White and Williams, 2010; Williams and Horodnic, 2018). For instance, buyers of informal products and services are depicted as paying kinship relations for undertaking home improvement tasks (e.g., painting) in order to give them money (e.g., if they are unemployed or have financial difficulties). In doing so, they avoid the notion that a charitable act is being engaged in, which might stop the person accepted the money from them (Kempson, 1996). Put another way, the buyer is not engaging in the informal economy for financial gain but instead, is helping a person in need of money, or helping friends, kin or colleagues. Here, therefore, the purchase of products and services from close social relations is a form of mutual aid rather than a profit-motivated monetary transaction (Williams and Horodnic, 2018; Zelizer, 2005). This social actor theory therefore directly challenges rational economic actor theory.

Formal economy failings rationale: neoliberal and institutional theory

A third theorisation for consumers intentionally buying products and services in the informal economy depicts such consumers as being pushed into the informal economy 


\section{Articles}

due to the failures of the formal economy. On the supply-side, participants in the informal economy are therefore viewed as intentionally exiting the formal economy. For neo-liberals, this is asserted to result from economic problems, such as over-complex registration systems and burdensome regulations, high taxes and corrupt public officials demanding bribes (Cross and Morales, 2007; De Soto, 1989, 2001; Maloney, 2004; Perry and Maloney, 2007; Small Business Council, 2004). For institutional theorists, this exit is more for social reasons. Participation in the informal economy is seen to arise when formal sector failings result in the laws and regulations a society's formal institutions not aligning with the norms, values and beliefs of employers and workers, namely its informal institutions (Godfrey, 2015; Webb et al, 2009; Williams and Horodnic, 2015). When formal and informal institutions are not aligned, participation in the informal economy is the result. Although it is a formally illegal activity it is viewed as socially legitimate (De Castro et al., 2014; Kistruck et al., 2015; Siqueira et al., 2016; Webb et al., 2013, 2014).

When applied to the purchase of products and services from the informal economy, the argument is therefore that these informal economy purchases are not due to the "pull" factors of the lower costs or social/redistributive reasons, but due to "push" factors related to the failures of the formal market. These formal market failings related to firstly, a lack of availability and reliability of formal market suppliers (e.g., formal enterprises may not offer some tasks or if they do, these enterprises might be unreliable), secondly, the speed at which products and services are delivered might be poor (pushing buyers in the informal economy to obtain goods or services quicker) and third and finally, the quality of the products and services obtained from the formal economy may be lower than when obtained through the informal economy. Unless these failures of the formal economy are tackled, then the argument is that purchases will persist in using the informal economy.

\section{Unintentional purchases from the informal economy}

In all these theoretical explanations for consumers buying goods and services from the informal economy, the underpinning assumption is that buyers are engaged in an intentional act. They intentionally purchase from the informal economy in order to either achieve a lower price, to help somebody, or due to the failings of the formal economy.

Nevertheless, supply-side studies increasingly recognise that participation in the informal economy can be unintentional. Employers or workers can be unaware of all the laws and regulations regarding tax, social insurance and labour law and might unintentionally violate these laws and regulations (Williams, 2018). This is potentially an important reason for participating in the informal economy. As Richardson (2006) shows in his analysis of 45 countries, regulatory complexity is the main determinant of tax non-compliance.

Despite this, no demand-side studies have so far considered that consumers might unintentionally acquire products and services from the informal economy and what proportion of all goods and services acquired from the informal economy are unintentional rather than deliberate informal purchases. This is important. All the above theories assumed that purchasing from the informal economy is an intentional act. This might not be the case. Purchasers might not know when they buy a good or service that it is being purchased from the informal economy and might only realise afterwards when no invoice or VAT receipt is given. Hence, it is necessary to evaluate not only the rationales for intentionally purchasing 


\section{Articles}

products and services in the informal economy but also to evaluate what proportion of informal purchases are not intentional.

\section{Competing or complementary theories}

No studies have so far evaluated the share of informal purchases of products and services that are unintentional. All previous studies have only evaluated the three theories above which assume that informal sector purchases are intentional. These evaluations include a study reporting a 2001 UK survey (Williams, 2008), a 2015 survey of three south-east European countries, namely Bulgaria, Croatia and North Macedonia (Williams and Bezeredi, 2017), a 2007 survey of 27 European countries (Williams and Martinez-Perez, 2014a,b), and a 2013 survey of 28 European countries (Williams et al., 2017) and 11 East-Central European countries (Williams and Horodnic, 2016). The finding across all these studies is that all three rationales are used by consumers when explaining their purchase of informal sector products and services. Williams and Martinez-Perez (2014a) find that in 2007, lower price is the sole motive for $44 \%$ of undeclared purchases, one of several rationales in $28 \%$ of acquisitions and not a rationale in $28 \%$ of purchases but is more common among marginalised groups. In 2013 and examining 28 European member states, Williams et al (2017) find that the lower cost rationale had declined in importance and was the sole reason provided for just 30\% of transactions (44\% in 2007), one of several rationales in a further $31 \%$ of purchases and absent in $39 \%$ of acquisitions (28\% in 2007). Taken together, therefore, these studies reveal that other rationales beyond a lower price had become more important between 2007 and 2013 in consumers' rationales for purchasing from the informal economy.

The only known study of the reasons for consumers' purchasing home repair and
Why do Consumers Buy from Informal Sector Suppliers in East-Central Europe?

renovation services from the informal sector (i.e., the study does not examine who does this) reports 2007 Eurobarometer survey data on 27 European member states (Williams et al, 2012). The finding is that a lower price is their only rationale in just $38 \%$ of cases where home repairs and renovations have been sourced from the informal economy, one of several rationales in $38 \%$ of instances and not cited as a motive in the remaining $24 \%$ of cases. In consequence, in $62 \%$ of instances where home repair and renovation services have been sourced from the informal economy, other reasons prevail besides achieving a lower price, and a lower price is wholly absent in one-quarter of all instances where home repairs and renovations have been sourced from the informal economy. Home repairs and renovations are sourced from the informal sector not only for social rationales but also to overcome failings of formal economy in terms of the availability, speed and quality of formal market provision. However, this study is based on data collected more than a decade ago in 2007 , only reports descriptive statistics, and thus does not evaluate who is more likely to cite each motive for sourcing informally when other variables are held constant.

Consequently, new data is here analysed to provide an up-to-date evaluation of firstly, who purchases home repair and renovation services from the informal economy, secondly, the prevalence of the three different motives for intentionally buying from informal sector home repairs and renovations as well as the proportion of such purchases which are unintentional, and third and finally, the population groups more likely to cite each motive for purchasing home repairs and renovations from the informal economy when other variables are held constant. 


\section{Methodology}

Data

To evaluate who purchases home repairs and renovations from the informal sector and their motives for doing so, data is reported from 11,171 face-to-face interviews undertaken in September 2019 in 11 East-Central European countries (Bulgaria, Czech Republic, Estonia, Hungary, Latvia, Lithuania, Poland, Romania, Slovakia, Slovenia and Croatia) for special Eurobarometer survey no. 498. Akin to all Eurobarometer surveys, a multi-stage random (probability) sampling methodology was used, which ensured that on the issues of gender, age, region and locality size, both the national and each level of the sample is representative in proportion to its population size. The total number of interviews was circa 1,000 in each country. All interviews were conducted in the national language with adults aged 15 years and older.

In this paper, the focus is upon those interview respondents who had purchased home repair and renovation services in the informal economy. Home repairs and renovations was the most common realm in which consumers purchased products and services in the informal economy. Some 30\% of all consumers who had purchased products and services in the informal economy in the past 12 months stated that they had purchased informal home repairs and renovations.

\section{Variables and Analytical Method}

To evaluate firstly, the population groups that are more likely to make purchases of home repair and renovation services from the informal economy and secondly, their motives and the characteristics of those asserting varying motives, a binary logistic regression analysis provides a suitable technique. The following variables are analysed.

\section{Dependent variables:}

- Informal purchase of home repair and renovation services - a dichotomous variable with recorded value 1 for persons who answered "yes" to the question "Have you in the last 12 months paid to buy undeclared goods and services for home repairs or renovations of which you had a good reason to assume that they included undeclared work (e.g. because there was no invoice or VAT receipt)?", and recorded value 0 otherwise.

To analyse their motives, multiple responses were possible to the question "Why did you buy these goods or services undeclared instead of buying them on the regular market?" (lower price; faster service; better quality; in order to help someone who needs money; it was a favour amongst friends/relatives/colleagues; good or service is not available on the regular market; they only realised afterwards it was undeclared). The responses are grouped as follows:

- Purely unintentional - a dichotomous variable with recorded value 1 for persons who solely answered "yes" to "You only realised afterwards that it was undeclared" and value 0 otherwise.

- Purely lower price - a dichotomous variable with recorded value 1 for persons who solely answered "yes" to "lower price" and with recorded value 0 otherwise.

- Purely social and/or redistributive reasons - this variable is measured with two dummy items with recorded value 1 for persons who answered "yes" to solely either "in order to help someone who is in need of money" and/or "it was a favour amongst friends/relatives/colleagues", and value 0 otherwise.

- Purely formal market failure - this variable is measured with three dummy items with recorded value 1 for persons who 


\section{Articles}

answered "yes" to solely either "lack of availability on regular market", "faster service undeclared" and/or "better service undeclared" and with recorded value 0 otherwise.

- Mixed motives - this is a dummy variable with recoded value 1 when the respondent selected at least two different sets of motive for purchasing undeclared home repairs and renovations, and 0 if less than two sets of motive.

Independent variables:

- Gender: a dummy variable with value 0 for women and 1 for men.

- Age: a categorical variable with value 1 for 15-24 years old, value 2 for aged 2539 years old, value 3 for $40-54$ years old and value 4 for $55+$ years old.

- Migration status: a dummy variable with value 0 for people who have not worked in other countries and value 1 for people who have worked in other countries.

- Employment status: a categorical variable grouping respondents by their occupation with value 1 for self-employed, value 2 for employed and value 3 for not working.

- Difficulties paying bills: a categorical variable for the respondents' difficulties in paying bills with value 1 for having difficulties most of the time, value 2 for occasionally, and value 3 for almost never/ never.

- People 15+ years in household: a categorical variable for people $15+$ years in respondent's household (including the respondent) with value 1 for one person, value 2 for two persons and value 3 for 3 persons or more.

- Children: a dummy variable for the presence of children aged up to 14 in the household with value 0 for individuals with no children and value 1 for those having children.
Why do Consumers Buy from Informal Sector Suppliers in East-Central Europe?

- Area: a categorical variable for the area where the respondent lives with value 1 for rural area or village, value 2 for small or middle-sized town, and value 3 for large town.

For the analysis of the descriptive statistics, sample weighting has been used to obtain meaningful descriptive results, as recommended in both the Eurobarometer methodology as well as in the wider literature (Solon et al., 2015; Winship and Radbill 1994). However, for the multivariate logistic regression analysis, and reflecting the dominant opinion in the wider literature on regression analysis, weighting has not been used (Solon et al., 2015; Winship and Radbill 1994).

It is important to briefly make mention of the reliability of the data before discussing the findings. The interviewers reported fair or excellent cooperation from the participant in $91 \%$ of the interviews, average cooperation in $8 \%$ and bad cooperation in $1.3 \%$. Therefore, although the informal economy is hidden from government enforcement authorities (e.g., tax administrations, labour inspectorates, social insurance institutions), this activity is hidden in plain sight in the sense that interviewees are willing to discuss it with researchers. Given this, the findings are now reported.

\section{Findings}

The overall finding is that $10 \%$ of the citizens surveyed across the 11 East-Central European countries had bought goods and services in the informal economy in the 12 months prior to the interview (compared with $11 \%$ of citizens in 2013 and $17 \%$ in 2007). Consequently, a gradually smaller proportion of the population is acquiring products and services in the informal economy over time. Evaluating what they bought in the informal economy, the finding is that $31 \%$ of informal sector purchases are home repairs and renovations. Indeed, this was the most 


\section{Articles}

common service bought by consumers from the informal economy. In consequence, 3.1\% of all East-Central European citizens surveyed had in the past 12 months purchased home repair and renovation services in the informal economy.

Who, therefore, is more likely to make these purchases in the informal economy and why do they do so? The first column in Table 1 reports the descriptive statistics on who purchases home repair and renovation services in the informal economy, and thus evaluates the marginalisation thesis. This displays that the propensity to purchase home repair and renovation services from the informal economy is greater among men, middle aged groups (aged 40-54 years old), the self-employed, those who have worked in other countries, those who have difficulties paying the bills most of the time, those who are living with three or more people in the household, and those living in larger urban areas. No differences indicated about those having children or not. As such, it only partially supports the marginalisation thesis. For example, although those who have difficulties paying the bills most of the time display a greater propensity to do so, this is not the case for those not working, women, younger age groups or rural populations. It displays, therefore, the need for a nuanced interpretation of the marginalisation thesis when discussing who sources home repair and renovation services in the informal economy.

Why do these citizens acquire their home repair and renovation services from the informal economy? In Table 1, citizens acquiring home repair and renovation services from the informal economy are grouped by whether they solely state: it was unintentional (they only realised afterwards it was undeclared); lower price (the rational economic actor explanation); faster service, better quality and/or the good/service is not/ hardly available on the regular market (the failures of the formal economy explanation), and it was favour amongst friends/relatives/ colleagues and/or in order to help someone who is in need of money (the social/ redistributive explanation). If they did not state purely these groups of responses, they were classified as possessing mixed motives.

Table 1. Prevalence and motives for purchasing home repair and renovation services in the informal economy in East-Central Europe: by population group, 2019

\begin{tabular}{|c|c|c|c|c|c|c|}
\hline & \multirow{2}{*}{$\begin{array}{c}\% \text { buying home repairs } \\
\text { or renovations in } \\
\text { informal economy }\end{array}$} & \multicolumn{5}{|c|}{$\begin{array}{l}\text { Motives for purchasing home repair and renovation services } \\
\text { in informal economy (\%) }\end{array}$} \\
\hline & & $\begin{array}{c}\text { Not } \\
\text { intentional }\end{array}$ & $\begin{array}{l}\text { Purely } \\
\text { lower cost }\end{array}$ & $\begin{array}{c}\text { Purely } \\
\text { formal sector } \\
\text { failures }\end{array}$ & $\begin{array}{l}\text { Purely social/ } \\
\text { redistributive }\end{array}$ & $\begin{array}{l}\text { Mixed } \\
\text { reasons }\end{array}$ \\
\hline Number & 346 & 14 & 69 & 44 & 44 & 175 \\
\hline All citizens & $3.1 \%$ & $3.6 \%$ & $20.0 \%$ & $12.8 \%$ & $12.8 \%$ & $50.6 \%$ \\
\hline \multicolumn{7}{|l|}{ Gender: } \\
\hline Man & $4.1 \%$ & $3.1 \%$ & $19.2 \%$ & $9.8 \%$ & $17.4 \%$ & $50.6 \%$ \\
\hline Women & $2.2 \%$ & $4.3 \%$ & $20.5 \%$ & $16.0 \%$ & $7.8 \%$ & $51.4 \%$ \\
\hline \multicolumn{7}{|l|}{ Age: } \\
\hline $15-24$ & $1.2 \%$ & $0.0 \%$ & $4.2 \%$ & $53.4 \%$ & $15.9 \%$ & $26.5 \%$ \\
\hline $25-39$ & $3.4 \%$ & $2.3 \%$ & $25.3 \%$ & $9.7 \%$ & $9.0 \%$ & $53.8 \%$ \\
\hline $40-54$ & $4.0 \%$ & $4.0 \%$ & $16.9 \%$ & $10.9 \%$ & $12.6 \%$ & $55.6 \%$ \\
\hline $55+$ & $3.0 \%$ & $4.6 \%$ & $19.8 \%$ & $9.3 \%$ & $18.6 \%$ & $47.7 \%$ \\
\hline
\end{tabular}




\begin{tabular}{|c|c|c|c|c|c|c|}
\hline & \multirow{2}{*}{$\begin{array}{l}\% \text { buying home repairs } \\
\text { or renovations in } \\
\text { informal economy }\end{array}$} & \multicolumn{5}{|c|}{$\begin{array}{l}\text { Motives for purchasing home repair and renovation services } \\
\text { in informal economy (\%) }\end{array}$} \\
\hline & & $\begin{array}{c}\text { Not } \\
\text { intentional }\end{array}$ & $\begin{array}{l}\text { Purely } \\
\text { lower cost }\end{array}$ & $\begin{array}{c}\text { Purely } \\
\text { formal sector } \\
\text { failures }\end{array}$ & $\begin{array}{l}\text { Purely social/ } \\
\text { redistributive }\end{array}$ & $\begin{array}{l}\text { Mixed } \\
\text { reasons }\end{array}$ \\
\hline \multicolumn{7}{|l|}{ Migration status: } \\
\hline Worked in other countries & $4.2 \%$ & $1.1 \%$ & $16.1 \%$ & $15.2 \%$ & $8.0 \%$ & $59.6 \%$ \\
\hline $\begin{array}{l}\text { Not worked in other } \\
\text { countries }\end{array}$ & $2.9 \%$ & $4.2 \%$ & $20.6 \%$ & $11.1 \%$ & $15.5 \%$ & $48.5 \%$ \\
\hline \multicolumn{7}{|l|}{ Employment status: } \\
\hline Self-employed & $5.0 \%$ & $1.9 \%$ & $17.7 \%$ & $4.1 \%$ & $6.4 \%$ & $69.9 \%$ \\
\hline Employed & $3.6 \%$ & $4.2 \%$ & $19.4 \%$ & $12.6 \%$ & $10.9 \%$ & $52.9 \%$ \\
\hline Not working & $2.3 \%$ & $2.8 \%$ & $20.8 \%$ & $13.6 \%$ & $21.7 \%$ & $41.0 \%$ \\
\hline \multicolumn{7}{|l|}{ Difficulties paying bills: } \\
\hline Most of time & $4.3 \%$ & $7.7 \%$ & $10.6 \%$ & $17.2 \%$ & $18.6 \%$ & $46.0 \%$ \\
\hline From time to time & $3.7 \%$ & $4.4 \%$ & $17.6 \%$ & $13.5 \%$ & $12.3 \%$ & $52.2 \%$ \\
\hline Almost never/never & $2.8 \%$ & $2.5 \%$ & $22.2 \%$ & $10.5 \%$ & $13.7 \%$ & $51.1 \%$ \\
\hline \multicolumn{7}{|c|}{ People 15+ years in own household: } \\
\hline One & $2.6 \%$ & $4.9 \%$ & $10.0 \%$ & $11.5 \%$ & $13.8 \%$ & $59.9 \%$ \\
\hline Two & $3.2 \%$ & $2.8 \%$ & $27.4 \%$ & $8.5 \%$ & $10.4 \%$ & $50.9 \%$ \\
\hline Three and more & $3.3 \%$ & $4.1 \%$ & $12.0 \%$ & $18.1 \%$ & $19.8 \%$ & $46.1 \%$ \\
\hline \multicolumn{7}{|l|}{ Children: } \\
\hline No children & $3.1 \%$ & $3.5 \%$ & $17.7 \%$ & $13.4 \%$ & $14.8 \%$ & $50.6 \%$ \\
\hline Having children & $3.1 \%$ & $3.6 \%$ & $24.7 \%$ & $8.4 \%$ & $11.8 \%$ & $51.5 \%$ \\
\hline \multicolumn{7}{|l|}{ Urban/rural: } \\
\hline Rural area or village & $2.9 \%$ & $5.0 \%$ & $17.2 \%$ & $8.0 \%$ & $22.2 \%$ & $47.6 \%$ \\
\hline Small or medium sized town & $3.2 \%$ & $2.1 \%$ & $28.2 \%$ & $6.8 \%$ & $9.1 \%$ & $53.8 \%$ \\
\hline Large town & $3.3 \%$ & $3.3 \%$ & $13.1 \%$ & $22.4 \%$ & $9.6 \%$ & $51.6 \%$ \\
\hline
\end{tabular}

Source: authors' calculations from special Eurobarometer survey no. 498, 2019

The finding is that $3.6 \%$ purely stated it was unintentional, $20.1 \%$ that it was purely to achieve a lower price, $12.8 \%$ that it was purely due to formal sector failings, $12.8 \%$ that is was purely for social and/or redistributive rationales and $50.6 \%$ reported mixed motives.

Some $8 \%$ include the rationale that they unintentionally bought home repair and renovation services from the informal economy in their response, and $3.6 \%$ state purely this as their reason. Hence, most purchases from the informal economy of home repair and renovation services are intentional. What, therefore, are their reasons for doing so?
The rational economic actor explanation that it was solely to achieve a lower price was stated by one-fifth $(20.1 \%)$ of consumers and a further $25.1 \%$ included lower price as one reason along with others related to poor formal provision and/or social/redistributive rationales. This reason is therefore wholly absent in $54.8 \%$ of purchases of homes repair and renovations from the informal economy. To explain purchases of home repair and renovation services from the informal economy, therefore, other reasons need to be incorporated into any explanation. Just under 1 in $8(12.8 \%)$ purchased informal sector home repair and renovations purely due to the 


\section{Articles}

failings of formal sector provision and 12.8\% purely for social and/or redistributive reasons. Who, therefore, more commonly cites each rationale?

Table 2 reports a binary logistic regression analysis on who is more likely to buy home repairs and renovations in the informal economy and the population groups that have a greater propensity to cite each explanation when other variables are controlled for and held constant. Column 1 in Table 2 reports the groups with a greater propensity to purchase home repairs and renovations in the informal economy. This reveals that the likelihood is significantly greater among men, older age groups, those having difficulties in paying their bills from time to time, those who are living in two adult households and the self-employed. This clearly reveals that the marginalisation thesis is not valid. It is not those who most of the time have difficulties paying the bills and neither is it those not working who are most likely to purchase home repairs and renovations in the informal economy. In part, this might be because such groups cannot afford to purchase home repairs and renovations either in the formal or informal economies, and instead et-by through unpaid self-provisioning, namely doing it themselves on an unpaid basis. This, therefore, might explain why marginalised populations are not more likely to buy home repairs and renovations from the informal economy.

Turning to the groups citing each explanation for purchasing home repair and renovation services from the informal sector, column 2 reveals that the propensity to cite that it was unintentional is significantly greater among older age groups than younger ones. Analysing the rational economic actor explanation of purely a lower price, this is significantly more likely to be stated by two-adult households. Interestingly, it is not significantly more likely to be stated by those not working or who most of the time have difficulties paying the household bills. These groups therefore are less likely to be influenced by governments changing the costbenefit ratio confronting them.

Table 2: Logit regressions of propensity to, and reasons for, purchasing home repairs or renovations from the informal economy in East-Central Europe, 2019

\begin{tabular}{|c|c|c|c|c|c|c|}
\hline & $\begin{array}{l}\% \text { purchasing } \\
\text { from informal } \\
\text { sector }\end{array}$ & $\begin{array}{c}\text { Purely } \\
\text { unintentional } \\
\text { rationale }\end{array}$ & $\begin{array}{l}\text { Purely lower } \\
\text { costs }\end{array}$ & $\begin{array}{l}\text { Purely formal } \\
\text { sector failure }\end{array}$ & $\begin{array}{l}\text { Purely social/ } \\
\text { redistributive }\end{array}$ & $\begin{array}{l}\text { Mixed } \\
\text { reasons }\end{array}$ \\
\hline Gender (RC: Women) & Coef. (S.E) & Coef. (S.E) & Coef. (S.E) & Coef. (S.E) & Coef. (S.E) & Coef. (S.E) \\
\hline Man & $.252(.119)^{\star \star}$ & $-.552(.495)$ & $-.200(.269)$ & $-.341(.325)$ & $.940(.351)^{\star \star *}$ & $.048(.205)$ \\
\hline Age (exact age) & $.326(.070)^{\star \star \star}$ & $.921(.404)^{\star \star}$ & $-.096(.173)$ & $.013(.202)$ & $.012(.214)$ & $-.094(.132)$ \\
\hline \multicolumn{7}{|c|}{ Migration status ( RC: Not worked in other countries) } \\
\hline Worked in other countries & $.096(.158)$ & $-.091(.677)$ & $.209(.342)$ & $.192(.418)$ & $-.882(.485)^{\star}$ & $.109(.266)$ \\
\hline \multicolumn{7}{|c|}{ Difficulties paying bills (RC: Almost never/never) } \\
\hline From time to time & $.255(.129)^{\star \star}$ & $-.835(.585)$ & $.179(.282)$ & $.234(.330)$ & $-.025(.350)$ & $-.044(.216)$ \\
\hline Most of time & $.056(.213)$ & $-.207(.809)$ & $-.341(.528)$ & $.062(.591)$ & $-.451(.670)$ & $.364(.376)$ \\
\hline \multicolumn{7}{|l|}{ Urban/rural (RC: Large towns } \\
\hline Rural area or village & $.134(.142)$ & $.470(.563)$ & $-.032(.336)$ & $-.338(.369)$ & $.592(.394)$ & $-.150(.244)$ \\
\hline Small or medium sized town & $.117(.141)$ & $.086(.613)$ & $.358(.320)$ & $-.595(.395)$ & $-.001(.429)$ & $.032(.246)$ \\
\hline \multicolumn{7}{|c|}{ People 15+ years in own household (RC: One) } \\
\hline Two & $.264(.154)^{\star}$ & $-.933(.572)$ & $.706(.383)^{\star \star}$ & $-.139(.412)$ & $-1.165(.442)^{\star * *}$ & $.262(.269)$ \\
\hline Three and more & $.241(.172)$ & $-.517(.659)$ & $.220(.446)$ & $.192(.462)$ & $-.034(.441)$ & $-.081(.304)$ \\
\hline \multicolumn{7}{|l|}{ Children (RC: No children) } \\
\hline Having children & $-.018(.139)$ & $.326(.622)$ & $.142(.315)$ & $-.810(.435)^{\star \star}$ & $.520(.379)$ & $-.066(.242)$ \\
\hline
\end{tabular}




\begin{tabular}{lllllll}
\hline & $\begin{array}{c}\text { \% purchasing } \\
\text { from informal } \\
\text { sector }\end{array}$ & $\begin{array}{c}\text { Purely } \\
\text { unintentional } \\
\text { rationale }\end{array}$ & $\begin{array}{c}\text { Purely lower } \\
\text { costs }\end{array}$ & $\begin{array}{c}\text { Purely formal } \\
\text { sector failure }\end{array}$ & $\begin{array}{c}\text { Purely social/ } \\
\text { redistributive }\end{array}$ & $\begin{array}{c}\text { Mixed } \\
\text { reasons }\end{array}$ \\
\hline $\begin{array}{l}\text { Employment status (RC: not working) } \\
\text { Self-employed }\end{array}$ & & & & & & \\
Employed & $.701(.211)^{\star * *}$ & $.103(.866)$ & $.440(.417)$ & $-1.279(.793)$ & $-1.364(.697)^{\star * *}$ & $.448(.350)$ \\
Constant & $.178(.138)$ & $.734(.601)$ & $-.422(.326)$ & $.070(.382)$ & $-.220(.398)$ & $.158(.249)$ \\
$\mathrm{N}$ & $-2.446^{* * *}$ & $-5.621(1.730)^{\star * *}$ & $-1.681(.779)^{\star *}$ & $-1.500(.888)^{*}$ & $-2.115(.945)^{\star *}$ & $.230(.585)$ \\
Nagelkerke R Square & 11171 & 450 & 450 & 450 & 450 & 450 \\
\hline
\end{tabular}

Significance: ${ }^{*} p<0.1,{ }^{* *} p<0.05,{ }^{* *} p<0.01$

Source: authors' calculations from special Eurobarometer survey no. 498, 2019

Who, therefore, displays a greater propensity to cite failures of formal market provision in terms of accessibility, quality and speed? This is significantly more likely to be stated by those who have children. Meanwhile, examining the groups significantly more or less likely to acquire home repairs or renovations from the informal sector due to social/redistributive rationales only are men, while those who have lived in other countries, two-adult households and the self-employed are significantly less likely to cite this explanation.

In sum, the conventional rational economic actor explanation that the main reason citizens buy home repairs and renovations from the informal economy is to achieve a lower price has been here shown to be the sole reason for only 1 in 5 purchasers. Many other explanations exist for purchasing home repairs and renovations from the informal economy, namely circumventing the shortcomings of formal market provision in terms of its availability, speed, reliability and quality, and social and redistributive rationales. Below, the implications for theorising and tackling this off-the-books consumer culture in the home repairs and renovations sector are discussed.

\section{Discussion and Conclusions}

This paper has revealed that $10 \%$ of citizens surveyed across 11 East-Central European countries had purchased products and services in the informal economy in the 12 months prior to the interview, and $31 \%$ of these purchased home repairs and renovations in the informal economy. Examining who is more likely to do so, the likelihood is significantly greater among men, older age groups, those having difficulties in paying their bills from time to time, those who are living in two adult households and the self-employed. This suggests that the marginalisation thesis that it marginalised populations such as those not working and with financial difficulties most of the time, does not appear valid, perhaps because these groups are more likely to selfprovision rather than pay for home repair or renovation services in either the formal or informal economy.

Turning to the citizens explanations for purchasing home repair and renovation services from the informal economy, a common a priori assumption has been that they purely do so because it is a lower price, exemplified in the popular statement "how much for cash?". Nevertheless, the finding is that a lower price is the only reason in just 1 in 5 (20.1\%) cases and one of several rationales in a further $25.1 \%$ of cases. Therefore, in $79.9 \%$ of cases, other rationales prevail and the desire for a lower price is wholly absent in over half $(54.8 \%)$ of purchases. Instead, citizens purchase home repairs and renovations from the informal economy for social reasons and to overcome the shortcomings of formal market providers in terms of the availability, speed and quality 


\section{Articles}

of provision. However, different types of EastCentral European citizen are significantly more likely to explain their participation in particular ways. Consumers significantly more likely to cite the motive of a lower price, and thus consumers more susceptible to alterations in the cost/benefit ratio, are two-adult households, whilst purely formal market failings are more likely to be cited by households with children and purely social rationales by men.

The outcome is that theoretical advances have been made. On the one hand, it reveals the need to replace the marginalisation thesis. Rather than view groups marginalised from the formal market as the purchasers of home repairs and renovations from the informal sector, a more nuanced theorisation is required which recognises that besides the choice between the formal or informal market when undertaking home repairs and renovations, there are other types of labour that can be used such as self-provisioning. This, therefore, suggests the need to examine the full range of labour practices available (see Williams, 2010). On the other hand, it reveals that when paid informal work is used to undertake home repairs and renovations, this is nearly always an intentional decision on the part of consumers. However, it is not simply chosen to achieve a lower price. Instead, consumers often choose informal sector services for either social and redistributive intentions, or because they are pushed by the lack of availability, speed and quality of formal market provision. To more fully explain the purchase of home repairs and renovations from the informal economy, therefore, the full range of explanations need to be used. All are relevant, albeit with variations in the propensity to state each motive across different populations. This research now needs repeating in other economic sectors and different global regions to evaluate whether similar findings prevail.
There are also important policy implications. Firstly, these findings provide some tentative indication of the consumer groups that need to be targeted by policy initiatives to prevent the purchase of home repairs and renovations from the informal economy, such as awareness raising campaigns about the costs of using informal suppliers (e.g., guarantees work will be undertaken to the required health and safety standards). These are older age groups, men, those living in two-adult households, the selfemployed and those with difficulties paying their bills from time to time. Secondly, these findings strongly indicate the type of policy measures needed. Conventionally, attempts have been made to alter the cost/benefit ratio confronting purchasers, such as by using tax rebates or service vouchers that reduce the cost of employing formal suppliers (European Platform Tackling Undeclared Work, 2019; Windebank, 2007). However, the findings of this study display that this changing the cost/benefit ratios confronting purchasers is necessary but insufficient. Purchases from the informal economy also result from the shortcomings of formal market provision and consumers pursuing social ends.

It is also necessary, therefore, to improve formal sector provision. One way of resolving the lack of availability and speed of formal market provision might be to develop local phone hotlines, sharing economy platforms and one-stop shops which purchasers can use to source formal sector suppliers, and formal suppliers can advertise. Meanwhile, resolving the quality and reliability of formal market provision requires the development of quality assurance systems to guarantee the quality and reliability of formal traders. Given that households with children are more likely to cite formal market failings as their reason for sourcing informal services, marketing of these hotlines, platforms, and quality assurance 


\section{Articles}

systems could be done via educational establishments. On tackling informal home repairs and renovations sourced for social rationales, consideration is required of whether to use a laissez-faire approach, tax incentives to employ formal market providers (e.g., vouchers or tax rebates), and/or develop new institutions to enable paid favours to be conducted legitimately, such as Local Exchange and Trading Schemes (LETS) and time banks (Valor and Papaoikonomou 2016).

Nevertheless, there are limitations to this study. It only considers one sector (i.e., home repair and renovation services). It also only considers East-Central Europe. It might be the case that the weight given to the different theorisations and policy initiatives will alter when different sectors and areas are evaluated. Future research is required to evaluate whether this is the case. Qualitative research would also be useful to more fully understand the logics and drivers underpinning decisions to source home repairs and renovations from the informal economy, and how decisions are taken about whether to use formal market provision, the informal sector, self-provisioning or unpaid mutual aid to get tasks completed.

In conclusion, if this paper stimulates a shift away from single uni-dimensional theorisations for purchasing products and services from the informal sector (e.g., lower cost) and towards recognition that there are multifarious rationales in different populations, this paper will have achieved one of its intentions. If governments then pay greater attention to the fuller range of demand-side policy initiatives needed and how they need to be targeted at different populations, then this paper will have achieved its fuller intention.
Why do Consumers Buy from Informal Sector Suppliers in East-Central Europe?

\section{References}

Allingham, M. and Sandmo, A., 1972. Income tax evasion: a theoretical analysis. Journal of Public Economics, 1(2), pp. 323-38.

Andrews, D., Caldera Sanchez, A. and Johansson, A., 2011. Towards a Better Understanding of the Informal Economy. Paris: OECD Economics Department Working Paper no. 873, OECD.

Bajada, C., 2002. Australia's Cash Economy: a troubling issue for policymakers. Aldershot: Ashgate.

Bourdieu, P., 2001. The forms of capital, in N.W. Biggart (ed.), Readings in Economic Sociology Oxford: Blackwell, 142-69.

Castells, M. and Portes, A., 1989. World Underneath: the origins, dynamics and effects of the informal economy, in $A$. Portes, $M$. Castells and L.A. Benton (eds.), The Informal Economy: studies in advanced and less developing countries. Baltimore: John Hopkins University Press, 19-42.

Chen, M., 2012. The Informal Economy: definitions, theories and policies. Manchester: WIEGO.

Cornuel, D. and Duriez, B., 1985. Local exchange and state intervention, in N. Redlclift and E. Mingione (eds.), Beyond Employment: household, gender and subsistence. Oxford: Basil Blackwell, 142-165.

Cross, J. and Morales, A., 2007. Introduction: locating street markets in the modern/ postmodern world, in J. Cross and A. Morales (eds.), Street Entrepreneurs: people, place and politics in local and global perspective. London: Routledge, 1-19.

Davis, M., 2006. Planet of Slums. London: Verso.

De Castro, J.O., Khavul, S. and Bruton, G.D., 2014. Shades of grey: how do informal firms navigate between macro and meso institutional 


\section{Articles}

environments? Strategic Entrepreneurship Journal, 8, pp. 75-94.

De Soto, H., 1989. The Other Path: the economic answer to terrorism. London: Harper and Row.

De Soto, H., 2001. The Mystery of Capital: why capitalism triumphs in the West and fails everywhere else. London: Black Swan.

Escobar, A., 1995. Encountering Development: the making and unmaking of the third world. Princeton: Princeton University Press.

European Commission, 1998. On Undeclared Work COM (1998) 219. Brussels: Commission of the European Communities.

European Commission, 2007. Stepping up the fight against undeclared work. Brussels: European Commission.

European Commission, 2016. Decision (EU) 2016/344 of the European Parliament and of the Council of 9 March 2016 on establishing a European Platform to enhance cooperation in tackling undeclared work, available at: http:// data.europa.eu/eli/dec/2016/344/oj (accessed 18 April 2020)

European Platform Tackling Undeclared Work, 2019. Preventative approaches for tackling undeclared work, focusing upon tax rebates and notification letters. Brussels: European Commission.

Fortin, B., Garneau, G., Lacroix, G., Lemieux, T. and Montmarquette, C., 1996. L'Economie Souterraine au Quebec: mythes et realites. Laval: Presses de l'Universite Laval.

Gallin, D., 2001. Propositions on trade unions and informal employment in times of globalisation. Antipode, 19(4), pp. 531-49.

Gibson-Graham, J-K., 2006. Post-capitalist Politics. Minneapolis: University of Minnesota Press.

Godfrey, P.C., 2015. Introduction: why the informal economy matters to management, in P.C. Godfrey (ed.), Management, Society, and the Informal Economy. London: Routledge, 1-20.

Grabiner, L., 2000. The Informal Economy. London: HM Treasury.

Hasseldine, J. and Li, Z., 1999. More tax evasion research required in new millennium. Crime, Law and Social Change, 31(1), pp. 91104.

ILO, 2015. Transitioning from the informal to the formal economy. Geneva: ILO.

ILO, 2018. Women and Men in the Informal Economy: statistical picture. Geneva: ILO.

Kempson, E., 1996. Life on a Low Income. York: York Publishing Services.

Kistruck, G.M., Webb, J.W., Sutter, C.J. and Bailey, A.V.G., 2015. The double-edged sword of legitimacy in base-of-the-pyramid markets. Journal of Business Venturing, 30(3), pp. 436451.

La Porta, R. and Shleifer, A., 2008. The unofficial economy and economic development. Brookings Papers on Economic Activity, 47(1), pp. 123-135.

La Porta, R. and Shleifer, A., 2014. Informality and development. Journal of Economic Perspectives, 28(3), pp. 109-126.

Leyshon, A., Lee, R. and Williams, C.C., 2003. Eds. Alternative Economic Spaces. London: Sage.

Loayza, N., 2018. Informality: why is it so widespread and how can it be reduced? Kuala Lumpur: Research \& Policy Brief no. 12, World Bank.

Maloney, W.F., 2004. Informality revisited. World Development, 32(7), pp. 1159-78.

Meagher, K., 2010. Identity economics: social networks and the informal economy in Nigeria. New York: James Currey.

Nelson, M.K. and Smith, J., 1999. Working Hard and Making Do: surviving in small town America. Los Angeles: University of California Press. 


\section{Articles}

OECD, 2017. Shining Light on the Shadow Economy: opportunities and threats. Paris: OECD.

Perry, G.E. and Maloney, W.F., 2007. Overview: Informality - exit and exclusion, in G.E. Perry, W.F. Maloney, O.S. Arias, P. Fajnzylber, A.D. Mason and J. Saavedra-Chanduvi (eds.), Informality: exit and exclusion. Washington DC: World Bank, pp. 142-168.

Persson, A. and Malmer, H., 2006. Purchasing and performing undeclared work in Sweden: part 1: results from various studies, available at: $\quad$ http://www.skatteverket.se/downlo ad/18.3dfca4f410f4fc63c8680003885/ swedish+report+200604B+.pdf (accessed 18 April 2020)

Richardson, G., 2006. Determinants of tax evasion: a cross-country investigation. Journal of International Accounting, Auditing and Taxation, 15(2), pp. 150-169.

Richardson, M. and Sawyer, A., 2001. A taxonomy of the tax compliance literature: further findings, problems and prospects. Australian Tax Forum, 16(2), pp. 137-320.

Sassen, S., 1997. Informalisation in Advanced Market Economies. Geneva: International Labour Office.

Shahid, M.S., Rodgers, P. and Williams, C.C., 2019. Reconceptualising informal work practices: some observations from an ethnic minority community in urban UK. International Journal of Urban and Regional Research, 43(3), pp. 476-496.

Siqueira, A.C.O., Webb, J.W. and Bruton, G.D., 2016. Informal entrepreneurship and industry conditions. Entrepreneurship Theory and Practice, 40(1), pp. 177-200.

Slavnic, Z., 2010. Political economy of informalisation. European Societies, 12(1), pp. 3-23.

Small Business Council, 2004. Small Businesses in the Informal Economy: making
Why do Consumers Buy from Informal Sector Suppliers in East-Central Europe?

the transition to the formal economy. London: Small Business Council.

Solon, G., Haider, S.J. and Wooldridge, J., 2013. What Are We Weighting for? Cambridge: Working Paper No. 18859, National Bureau of Economic Research.

Taiwo, O., 2013. Employment choice and mobility in multi-sector labour markets: theoretical model and evidence from Ghana. International Labour Review, 152(3-4), pp. 469-92.

Valor, C. and Papaoikonomou, E., 2016. Time banking in Spain: exploring their structure, management and users profile. Revista Internacional de Sociología, 74(1), pp. 28-42.

Venkatesh, S.A., 2006. Off the books: The underground economy of the urban poor. Cambridge MA: Harvard University Press.

Webb, J.W., Bruton, G.D., Tihanyi, L. and Ireland, R.D., 2013. Research on entrepreneurship in the informal economy: framing a research agenda. Journal of Business Venturing, 28(5), pp. 598-614.

Webb, J.W., Ireland, R.D. and Ketchen, D.J., 2014. Toward a greater understanding of entrepreneurship and strategy in the informal economy. Strategic Entrepreneurship Journal, 8, pp. 1-15.

Webb, J.W., Tihanyi, L., Ireland, R.D. and Sirmon, D.G., 2009. You say illegal, I say legitimate: entrepreneurship in the informal economy. Academy of Management Review, 34(3), pp. 492-510.

White, R. and Williams, C.C., 2010. Re-thinking monetary exchange: some lessons from England. Review of Social Economy, 68(3), pp. 317-38.

Williams, C.C., 2008. Consumers' motives for buying goods and services on an off-thebooks basis. International Review of Retail, Distribution and Consumer Research, 18(4), pp. 405-421. 


\section{Articles}

Williams, C.C., 2010. Beyond the market/nonmarket divide: a total social organisation of labour approach. International Journal of Social Economics, 37(6), pp. 402-414.

Williams, C.C., 2014. Confronting the Shadow Economy: evaluating tax compliance and behaviour policies. Cheltenham: Edward Elgar.

Williams, C.C., 2017. Entrepreneurship in the Informal Sector: an institutional perspective. London: Routledge.

Williams, C.C., 2018. Elements of a preventative approach towards undeclared work: an evaluation of service vouchers and awareness raising campaigns. Brussels: European Commission.

Williams, C.C., 2019a. Explaining and tackling the informal economy: an evaluation of competing perspectives. Open Economics, 2, pp. 63-75.

Williams, C.C., 2019b. Tackling undeclared work in the European Union: an evaluation of government policy approaches. UTMS Journal of Economics, 10(2), 135-147.

Williams, C.C., 2020a. An institutional theory of tax non-compliance in Bulgaria: a tax morale approach. Economic Alternatives, 26(1), pp. 33-49

Williams, C.C., 2020b. Explaining variations in the magnitude of undeclared work across the 28 European Union member states. Economic Alternatives,

Williams, C.C. and Bezeredi, S., 2017. Explaining consumers' motives for purchasing from the informal economy: some lessons from a study of Bulgaria, Croatia and FYR Macedonia. Economic Alternatives, 2(4), pp. 515-531.

Williams, C.C. and Bezeredi, S., 2019. Explaining and tackling unregistered employment: evidence from an employers' survey. Journal of Contemporary Central and Eastern Europe, 27(2-3), pp. 173-189.
Williams, C.C. and Efendic, A., 2020. Evaluating the relationship between migration and participation in undeclared work: lessons from Bosnia and Herzegovina. Economic Alternatives,

Williams, C.C. and Horodnic, I., 2015. Evaluating the prevalence of the undeclared economy in Central and Eastern Europe: an institutional asymmetry perspective. European Journal of Industrial Relations, 21(4), pp. 389406.

Williams, C.C. and Horodnic, I., 2016. Evaluating the multifarious motives for acquiring goods and services from the informal sector in Central and Eastern Europe. Journal of Contemporary Central and Eastern Europe, 24(3), pp. 321-338.

Williams, C.C. and Horodnic, I., 2017. Who participates in undeclared work in the European Union? towards a reinforced marginalisation perspective. International Journal of Sociology, 47(2), pp. 99-115

Williams, C.C. and Horodnic, I., 2018. Reconceptualising undeclared work as paid favours: implications for community economic development. Community Development Journal, 53(4), pp. 732-750

Williams, C.C. and Horodnic, I., 2019. Evaluating working conditions in the informal economy: evidence from the 2015 European Working Conditions Survey. International Sociology, 34(3), pp. 281-306.

Williams, C.C. and Martinez-Perez, A., 2014a. Why do consumers purchase goods and services in the informal economy? Journal of Business Research, 67(5), pp. 802-806.

Williams, C.C. and Martinez-Perez, A., 2014b. Evaluating the cash-in-hand consumer culture in the European Union. Journal of Contemporary European Studies, 22(4), pp. 466-482.

Williams, C.C. and Puts, E., 2017. European Platform Undeclared Work 2017 Platform 


\section{Articles}

Survey Report: organisational characteristics of enforcement bodies, measures adopted to tackle undeclared work, and the use of databases and digital tools. Brussels: European Commission.

Williams, C.C. and Yang, J., 2017. Tackling falsely-declared salaries in Bulgaria: evidence from a 2015 survey. Economic Alternatives, 3, pp. 333-351

Williams, C.C. and Yang, J., 2018. Evaluating competing perspectives towards undeclared work: some lessons from Bulgaria. Journal of Contemporary Central and Eastern Europe, 26(2-3), pp. 247-265.

Williams, C.C., Nadin, S. and Windebank, J., 2012. How much for cash? Tackling the cashin-hand culture in the European property and construction sector. Journal of Financial Management of Property and Construction, 17(2), pp. 123-134.

Williams, C.C., Round, J. and Rodgers, P., 2013. The Role of Informal Economies in the
Why do Consumers Buy from Informal Sector Suppliers in East-Central Europe?

Post-Soviet World: the end of transition? London: Routledge.

Williams, C.C., Horodnic, I. and Windebank, J., 2017. Explaining participation in the informal economy: a purchaser perspective. International Journal of Social Economics, 44(11), pp. 1421-143

Williams, C.C., Yalaman, G.O. and Kedir, A., 2020. Evaluating Policy Approaches Towards Tackling Undeclared Work in the Czech Republic. Economic Alternatives,

Windebank, J., 2007. Outsourcing women's domestic labour: the chèque emploi-service universel in France. Journal of European Social Policy, 17(3), pp. 257-70.

Winship, C., and Radbill, L., 1994. Sampling Weights and Regression Analysis. Sociological Methods and Research, 23(2), pp. 230-257.

World Bank, 2019. Global Economic Prospects: Darkening Skies. Washington DC: World Bank.

Zelizer, V., 2005. The Purchase of Intimacy. Princeton: Princeton University Press. 